\section{Nyttig om norske helse- og sosialordninger}

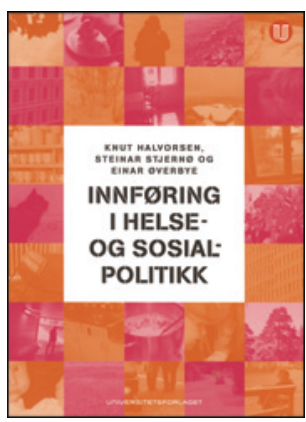

\author{
Knut Halvorsen, Steinar Stjernø, \\ Einar Øverbye \\ Innføring i helse- og sosialpolitikk
}

281 s, tab, ill. Oslo: Universitetsforlaget, 2013 Pris NOK 429

ISBN 978-82-15-02196-6

Trenger du en oppslagsbok om sosiale ordninger og de mest sentrale spørsmålene innen helsetjenesten, er dette boken for deg. Lurer du for eksempel på hva som var hovedtrekkene i omleggingen av alderspensjonen for noen år siden, og hvilke grunner myndighetene ga for reformen, finner du en kort og velskrevet oversikt her. Eller spør en pasient deg om advokaten har rett $i$ at samboeren kan kreve underholdsbidrag når han bare er sammen med barnet en dag i måneden, finner du raskt både regelen og praksisen omkring slike tvister. Om du trenger en kort gjennomgang av hvordan helseforetakene ble innført, og hvordan de har fungert, finner du det her.

Noen vil svare at nettet er mye bedre enn en bok som snart er utdatert. Det er riktig når det gjelder informasjon om de siste reglene, men ikke når det gjelder kunnskap om reglenes bakgrunn og bruk i praksis. Dessuten endrer de aller fleste reglene seg svært sjelden i det store apparatet som utgjør sosiale ordninger i Norge.

Dette er femte utgave av en grunnleggende lærebok ved sosialarbeider- og helselinjene ved høyskolene. Den omfatter et stort antall temaer, fra velferdsstatens historie over barnevern og familierett til trygdens mange regler og deres bakgrunn. Begrepet «helseog sosialpolitikk» kan virke misvisende, for her gjennomgås først og fremst et stort antall ordninger. Men i tillegg får vi også den politiske bakgrunnen for ordningene. Boken gir dertil gode oversikter over den ideologiske bakgrunnen for uenighetene på en lang rekke av disse områdene. Dette er en fin kombinasjon av regelverk, praksis og politikk.

Boken er velskrevet og godt avbalansert. Jeg finner ingenting å sette fingeren på. Den er godt egnet til formålet som lærebok på høyskolene og anbefales andre som vil lese om større eller mindre deler av sosial- og helsevesenet i vid betydning av ordene.

\section{Tendensiøs bok som ikke tilfører noe nytt}

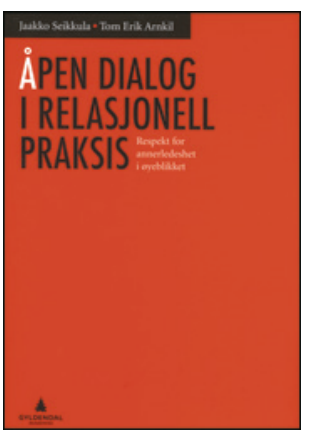

Jaakko Seikkula, Tom Erik Arnkil
Åpen dialog i relasjonell praksis

Respekt for annerledeshet i øyeblikket.

204 s, ill. Oslo: Gyldendal Akademisk, 2013

Pris NOK 325

ISBN 978'-82-05-44860-5

Målgruppen er profesjoner som arbeider innen psykoterapi, skole, utdanning og med sosialt arbeid, men i tillegg ønsker forfatterne å nå ut til lesere som ikke har slik fagbakgrunn. Forfatterne har bakgrunn fra systemisk familieterapi og har funnet behov for mer åpen dialog enn hva tradisjonell systemisk praksis inviterer til. De forsøker å beskrive en teori for åpen dialog.

I de ti kapitlene prøver forfatterne å illustrere teorien med kliniske/praktiske eksempler fra ulike dialoger. Jeg synes eksemplene i liten grad evner å klargjøre teorien som presenteres.

Hva handler så boken om? I hovedsak sies det på 200 sider at man må ha respekt for den Andres unike annerledeshet. Det er et selvfølgelig budskap som det er lett å være enig i. Men når teorien forsøkes presentert, blir det underliggende, enkle temaet fremmedgjort. Sitat: «Både åpen dialog og foregripende dialog eller fremtidsdialog er basert på ideen om språkets multiplisitet (heteroglotprinsippet) og sosiale språk.»

Forfatterne ønsker å undersøke dialogens kjerneelementer, men jeg synes ikke de lykkes med sitt formål. Snarere bidrar boken til forvirring og fremmedgjøring.

Boken avsluttes med et kapittel om forskning, der egen metode og resultater ganske kritikkløst forherliges, mens mer tradisjonell forskning og behandlingsveiledere avskrives som ikke relevante eller ugyldige.

Forfatterne lever altså ikke helt opp til det de selv prediker: Møt den Andre med respekt.

Etter min mening er dette en bok det ikke er verdt å sette av tid til.

\title{
Synnøve Bratlie
}

Psykiater, Dr. Bratlies spesialistpraksis

Oslo 